\title{
Biosorption of $\mathrm{Cr}$ (VI) and $\mathrm{Cu}(\mathrm{II})$ by Palm Kernel Powder and Its Potential Application
}

\author{
Ragwan Mohamed, Alaa Mustafa, and Mohamed Erhayem
}

\begin{abstract}
In this research, palm kernel powder (PKP) was utilized as a bioadsorbent for the removal of $\mathrm{Cr}(\mathrm{VI})$ and $\mathrm{Cu}(\mathrm{II})$ ions from aqueous solutions. Batch studies were preformed to evaluate the effect of various experimental parameters on $\mathrm{Cr}(\mathrm{VI})$ and $\mathrm{Cu}(\mathrm{II})$ adsorption onto PKP. The adsorption equilibrium was reached after $70 \mathrm{~min}$. The adsorption capacity of $\mathrm{Cr}(\mathrm{VI})$ and $\mathrm{Cu}(\mathrm{II})$ was $\mathrm{pH}$-dependent showing a maximum at equilibrium pH 2 and 5, respectively. The percentage removal of heavy metals by PKP varied in order unmodified adsorbents $>$ HNO3 $>$ H3PO4. The adsorption isotherm and kinetics of $\mathrm{Cr}(\mathrm{VI})$ and $\mathrm{Cu}(\mathrm{II})$ were also investigated using Langmuir and Freundlich adsorption isotherm models and pseudo-first order (LSO) and pseudo-second-order (PSO) kinetic models. The data was better described by Freundlich adsorption isotherm model and PSO kinetics in the concentration range studied. For environmental study, it was found that the adsorption capacity for heavy metals decreased in the raw waste water sample in comparison with the synthetic waste water system.
\end{abstract}

Index Terms-Biosorption, chromium, copper, kinetics, palm kernel powder.

\section{INTRODUCTION}

Heavy metals, such as $\mathrm{Cr}(\mathrm{VI})$ and $\mathrm{Cu}(\mathrm{II})$, release into the environment from plating plants, mining, metal finishing, welding and alloy manufacturing pose a significant threat to the environment and public health [1]. Unlike some organic pollutants, $\mathrm{Cr}(\mathrm{VI})$ and $\mathrm{Cu}(\mathrm{II})$ are not biodegradable and cannot be metabolized or decomposed [2]. The major concern with $\mathrm{Cr}(\mathrm{VI})$ and $\mathrm{Cu}(\mathrm{II})$ is their ability to accumulate in the environment and cause public health problems. For instance, the toxicity of $\mathrm{Cr}(\mathrm{VI})$, even in small concentrations, has been extremely studied causing damage to kidney, liver, etc [3]. The excessive intake of $\mathrm{Cu}(\mathrm{II})$ leads to severe mucosal irrational, widespread capillary damage, hepatic and renal damage, central nervous problems followed by depression, gastrointestinal irritation, and possible necrotic changes in the liver and kidney [4].

Several studies have successfully investigated the removal of heavy ions, such as $\mathrm{Pb}(\mathrm{II}), \mathrm{Cd}(\mathrm{II}), \mathrm{Cr}(\mathrm{II}), \mathrm{Cu}(\mathrm{II}), \mathrm{Zn}$ (II), from aqueous solutions under various operating variables like contact time, solution $\mathrm{pH}$, initial metal concentration and temperature by agricultural by-products such as coconut shell charcoal, commercial activated carbon, Cankiri bentonite,

Manuscript received June 2, 2015; revised August 26, 2015

Ragwan Mohamed and Mohamed Erhayem are with Chemistry Department, University Sirte, Sirte, Libya (e-mail: ragwan3000@yahoo.com irhim2002@yahoo.co.uk).

Alaa Mustafa is with the Department of Environmental Science, Alexandria University, Alexandria, Egypt. natural zeolite clinoptilolite, egg shells, palm shell activated carbon and green alga Spirogyra species using different models and techniques [4]-[6]. The PKP was found to be poor adsorbent using different activation process [4]. This study focuses on the PK collected from Libya as almost zero cost adsorbent for removal of $\mathrm{Cr}(\mathrm{VI})$ and $\mathrm{Cu}(\mathrm{II})$.

\section{EXPERIMENTAL METHODS}

\section{A. Instruments}

The FT-IR spectra of PKP before and after addition of heavy metals were done using Nicolet Impact 410 (Bruker-Tensor37) equipment and the spectra were recorded from 400 to $4000 \mathrm{~cm}^{-1}$. The adsorption studies of metal ions were determined by using Atomic Absorption Spectrophotometer (AAS), Thermo AA spectrometer/M series. The $\mathrm{pH}$ value was measured by using $\mathrm{pH}$ meter (OAKTON 510 Series).

\section{B. Materials}

Raw material PK was collected from north of Libya and washed with distilled water and dried at $110^{\circ} \mathrm{C}$ for $24 \mathrm{~h}$. It was crushed and sieved to a particle size with $0.5 \mathrm{~mm}$ membrane and socked in $\mathrm{HNO}_{3}(60 \%)$ for $3 \mathrm{hrs}$. The mixture was washed with distilled water. The PK was heated at $230^{\circ} \mathrm{C}$ for $3 \mathrm{hrs}$ and then stored in desiccator. Synthetic stock solutions of $\mathrm{Cr}(\mathrm{VI})$ and $\mathrm{Cu}(\mathrm{II})$ were prepared by dissolving of $\mathrm{K}_{2} \mathrm{Cr}_{2} \mathrm{O}_{7}$ and $\mathrm{CuSO}_{4} .5 \mathrm{H}_{2} \mathrm{O}$, respectively, in deionized water. For the environmental study, raw waste water sample was collected from El-Souif waste crater plant, Alexandria, Egypt and 3 drops of $\mathrm{HNO}_{3}$ were added to prevent metal precipitation. The sample was transferred to the laboratory and filtered. The filtered sample conditions were: original concentration of $0.181 \mathrm{mgL}^{-1} \mathrm{Cr}(\mathrm{VI})$ and 0.144 and $\mathrm{mgL}^{-1} \mathrm{Cu}(\mathrm{II})$, respectively, the $\mathrm{pH}$ of 7 , salinity $2.68 \mathrm{mgL}^{-1}$, conductivity $557 \mathrm{~ms}$, TSS $200 \mathrm{mgL}^{-1}$ and TDS $430 \mathrm{mgL}^{-1}$.

\section{Adsorption Studies}

In order to evaluate the time at which the equilibrium of metal ions and PKP was attained, $50 \mathrm{mg}$ of PKP was added to $1.0 \mathrm{mgL}^{-1}$ of each metal ion solutions. The suspensions were then shacked at $200 \mathrm{rpm}$. The samples were taken for different time intervals (1, 2, 3, 4, 5, 10, 15, 25, 40 and $70 \mathrm{~min})$. In order to evaluate the effect of sorbent dosage on biosorption process, 0.1 to $1.0 \mathrm{~g}$ PKP doses were added to $150 \mathrm{~mL}$ of 1.0 $\mathrm{mgL}^{-1}$ of metal ion solutions. The $\mathrm{Cr}(\mathrm{VI})$ and $\mathrm{Cu}(\mathrm{II})$ solutions were adjusted to the desire $\mathrm{pH} 3$ and 5 (based on pH study). The effect of metal ion concentration on biosorption process was investigated using $1,5,10,20,50$, and $100 \mathrm{mLL}^{-1}$ of 150 $\mathrm{ml}$ of metal ion solutions, $\mathrm{Cr}(\mathrm{VI})$ and $\mathrm{Cu}(\mathrm{II})$, containing 50 
$\mathrm{mg}$ of PKP at constant $\mathrm{pH} 3$ and 5. In order to determine the effect of $\mathrm{pH}$ on biosorption process, $50 \mathrm{mg}$ of PKP (based on dosage study) was added to $150 \mathrm{ml}$ of $1 \mathrm{mgL}^{-1}$ of the metal ions at various values of $\mathrm{pH}$ from 3.0 to 9.0 using $0.1 \mathrm{~N} \mathrm{HCl}$ or $0.1 \mathrm{~N} \mathrm{NaOH}$. In order to obtain the adsorption isotherms by using batch equilibrium method, 50mg of PKP were added to $150 \mathrm{ml}$ of various concentrations $\left(1-1000 \mathrm{mgL}^{-1}\right)$ of $\mathrm{Cr}(\mathrm{VI})$ or $\mathrm{Cu}(\mathrm{II})$. All suspensions were stirred at $200 \mathrm{rpm}$ for $70 \mathrm{~min}$ to allow the suspension to equilibrate. The suspensions were allowed to settle down before filtering by Whatman $0.45 \mu \mathrm{m}$ filter paper. The remained metal concentrations were determined using AAS.

\section{Environmental Study}

In order to study the environmental impact of metal ions on biosorption process, $150 \mathrm{ml}$ of the raw waste water sample was treated with $50 \mathrm{mg}$ of PKP and continuous stirring at 200 rpm for $70 \mathrm{~min}$. The adsorption procedures described above were followed. All experiments were carried out twice and the data was the means of duplicated experimental results.

\section{RESULTS AND DISCUSSION}

Characterization of PKP. FT-IR spectra were recorded for the raw PKP before metal ion addition and showed the presence of different functional groups (-C-C-, $-\mathrm{OH}, \mathrm{N}-\mathrm{H}$, $-\mathrm{C}=\mathrm{C}-$ and $\mathrm{COOH}$ ), Figures not shown. The effect of solvent on these functional groups was also studied. These groups were affected by acid modification, namely solvent effect. The addition of $\mathrm{Cr}(\mathrm{VI})$ and $\mathrm{Cu}(\mathrm{II})$ caused to significantly decrease in the intensity and shift peaks of the functional groups due to $\mathrm{Cr}(\mathrm{VI})$ and $\mathrm{Cu}(\mathrm{II})$ adsorption onto PKP. This shift in wave number corresponds to a change in bonding energy of the functional groups. The $-\mathrm{C}-\mathrm{O}-,-\mathrm{C}=\mathrm{C}-$, $-\mathrm{C}=\mathrm{C}-,-\mathrm{C}=\mathrm{N}-,-\mathrm{OH},-\mathrm{COOH}$ and $-\mathrm{NH}$ groups are the most effective functional groups in $\mathrm{Cr}(\mathrm{VI})$ adsorption onto $\mathrm{PKP}$ surface functional groups. It can be noticed that $\mathrm{Cu}$ (II) adsorption was at $-\mathrm{C}-\mathrm{C}$ - and $-\mathrm{C}-\mathrm{O}$ - groups in case of raw $\mathrm{PKP}$ while in case of nitric and phosphoric acid modified $\mathrm{PKP}$ $\mathrm{Cu}(\mathrm{II})$ adsorption mainly occurred at $-\mathrm{C}-\mathrm{O}-,-\mathrm{OH},-\mathrm{COOH}$ and -NH groups.

Adsorption studies. Generally, the adsorption of $\mathrm{Cr}(\mathrm{VI})$ and $\mathrm{Cu}$ (II) ions showed a similar trend with time, which an initial rapid adsorption after the addition of PKP, followed by a final leveling off, Fig. 1. This is due to the availability of the PKP surface area and large numbers of vacant binding sites, which are available for adsorption during the initial stage of the addition and the surface gradually become covered with the metal ions after $40 \mathrm{~min}$. The AA data indicated no significant changes in the adsorption of $\mathrm{Cr}(\mathrm{VI})$ and $\mathrm{Cu}$ (II) ions on the PKP that occurred after $60 \mathrm{~min}$ due to the repulsive forces between the metal ions on the solid and liquid phases. This result is in good agreement with previous research [7], [8]. Therefore, $70 \mathrm{~min}$ was chosen as the time at which the adsorption of $\mathrm{Cr}(\mathrm{VI})$ and $\mathrm{Cu}$ (II) ions onto the PKP was attained. Also, the adsorption reactions of $\mathrm{Cr}(\mathrm{VI})$ and $\mathrm{Cu}$ (II) were performed after modification of the used adsorbents by $\mathrm{HNO}_{3}$ and $\mathrm{H}_{3} \mathrm{PO}_{4}$. The results indicated that the equilibrium time was shorter than that in case of unmodified adsorbents. Also, the percentage removal and adsorption capacity increased in case of modified adsorbents with $\mathrm{HNO}_{3}$, which was more effective in removing heavy metals than $\mathrm{H}_{3} \mathrm{PO}_{4}$. This could be due to heavy metals were not soluble in the presence of $\mathrm{H}_{3} \mathrm{PO}_{4}$ comparing to the presence of $\mathrm{HNO}_{3}$.
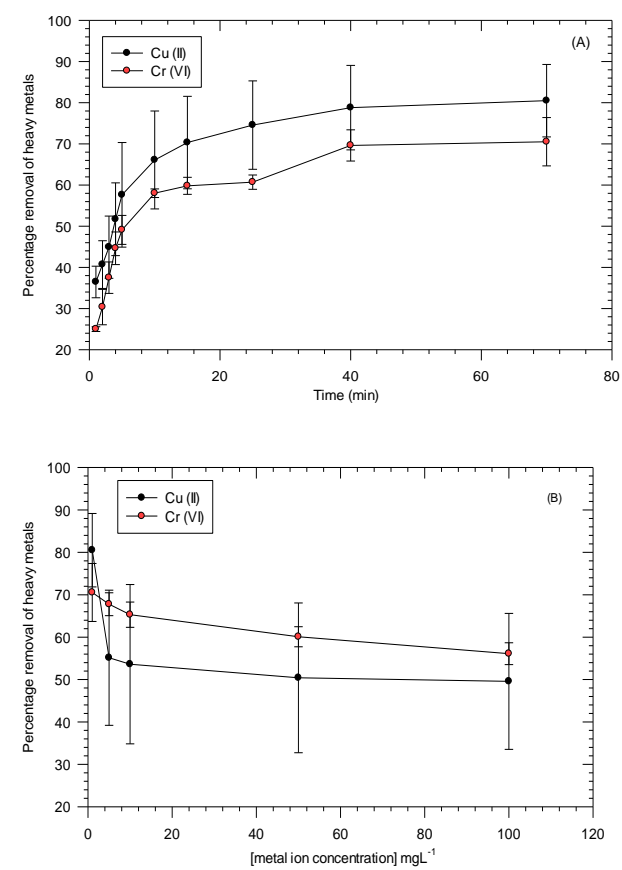

Fig. 1. Effect of (A) time and (B) ion metal concentrations on the percentage removal of $\mathrm{Cr}(\mathrm{VI})$ and $\mathrm{Cu}(\mathrm{II})$ onto PKP. (A) Fifty $\mathrm{mg}$ of PKP was added to 1 $\mathrm{mgL}^{-1}$ of each metal ion solutions. (B) Fifty mg of PKP was added to $150 \mathrm{ml}$ of $1-100 \mathrm{mgL}^{-1}$ of the metal ions. The $\mathrm{pH}$ value was adjusted to 3 for $\mathrm{Cr}(\mathrm{VI})$ and 5 for $\mathrm{Cu}$ (II). The suspensions were stirred at $200 \mathrm{rpm}$ for $70 \mathrm{~min}$ at $25^{\circ} \mathrm{C}$.

The effect of initial metal concentration on the adsorption process was investigated. Fig. 1 shows a decrease in the adsorption percentage of $\mathrm{Cr}(\mathrm{VI})$ and $\mathrm{Cu}(\mathrm{II})$ with a corresponding increase in initial concentration of metal ions. The trend which was an initial rapid adsorption of metal ions after addition of PKP followed by desorption and then a finial leveling off. Furthermore, the AA data indicated no significant changes in adsorption of metal ion onto PKP at high metal concentration likely due to the sites in the sorbents were occupied at higher concentration and fewer available sites were involved in the sorption process [9]. On the other hand, the adsorption capacity increased with increasing the initial concentration. This is probably due to the increasing initial metal concentration provides a key driving force to overcome all mass transfer resistance of metal ions between the aqueous and solid phases, thus increasing the adsorption capacity [10].

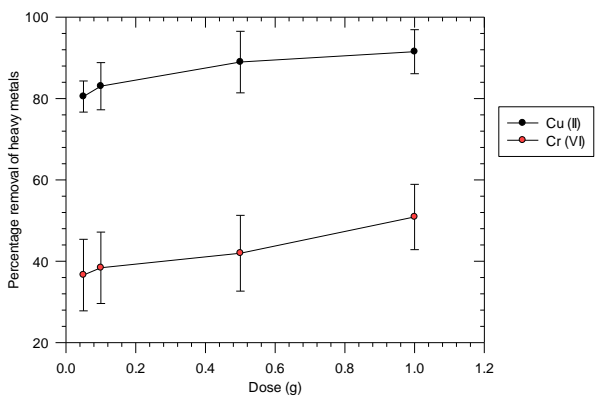

Fig. 2. Effect of PKP dose on the percentage removal of $\mathrm{Cr}(\mathrm{VI})$ and $\mathrm{Cu}(\mathrm{II})$ onto PKP. 0.1 to $1 \mathrm{~g}$ PKP doses were added to $150 \mathrm{~mL}$ of $1.0 \mathrm{mgL}^{-1}$ of metal ion solutions. The $\mathrm{pH}$ value was adjusted to 5 and the suspensions were stirred at $200 \mathrm{rpm}$ for $70 \mathrm{~min}$ at $25^{\circ} \mathrm{C}$. 
The effect of PKP dosage on the adsorption process was also studied, Fig. 2. An increase in adsorbent dosage resulted in a corresponding slightly increase in removal. This is likely due to the availability of more empty binding sites at higher dosages to adsorb the same amount of $\mathrm{Cr}(\mathrm{VI})$ and $\mathrm{Cu}(\mathrm{II})$ ions in the adsorbate solution [11]. The percentage removal of metal ions by PKP followed the order: $\mathrm{Cu}(\mathrm{II})>\mathrm{Cr}(\mathrm{VI})$ likely due to overlapping of adsorption sites as a result of overcrowding of adsorbent particles and the lower adsorbate to binding site ratio where the $\mathrm{Cr}(\mathrm{VI})$ ions were distributed onto larger amount of adsorbent binding sites [12]. Also, neutralization of the charge on the PKP surface due to metal ion adsorption and the anionic radii of $\mathrm{Cu}(\mathrm{II})>\mathrm{Cr}(\mathrm{VI})$, lead to an increase in the surface area onto PKP for adsorption.

Fig. 3 shows the effect of solution $\mathrm{pH}$ on biosorption process. The percentage removal of $\mathrm{Cr}(\mathrm{VI})$ adsorption onto PKP decreased significantly with increasing $\mathrm{pH}$ value and the maximum removal of $\mathrm{Cr}(\mathrm{VI})$ ions was found to be at $\mathrm{pH} 3$. The improved removal of chromium (VI) at low $\mathrm{pH}$ value is probably due to reduction of $\mathrm{Cr}(\mathrm{VI})$ to $\mathrm{Cr}$ (III) which in turn adsorbed into the surface active sites [13]. Also, the increase of $\mathrm{Cr}(\mathrm{VI})$ adsorption at acidic $\mathrm{pH}$ should be due to the electrostatic attraction between positively charged groups of the sorbent surface and the $\mathrm{HCrO} 4$ - anion which was the dominant species at low $\mathrm{pH}$ thereby increased the diffusion of chromate ions into the bulk of the adsorbent. Furthermore, $\mathrm{Cr}(\mathrm{VI})$ exists in aqueous medium as ( $\mathrm{HCrO} 4-, \mathrm{Cr} 2 \mathrm{O} 72-$, CrO4 2-) forms, among which the $\mathrm{HCrO} 4-$ form is the dominant species. Increasing the $\mathrm{pH}$ shifts the concentration of $\mathrm{HCrO} 4-$ to other forms, i.e., $\mathrm{CrO} 42-$ and $\mathrm{Cr} 2 \mathrm{O} 72-$. Consequently, $\mathrm{Cr}(\mathrm{VI})$, existing as oxo anions in water, which decreases in the adsorption due to the increased number of $\mathrm{OH}^{-}$ions in the bulk which retarded the diffusion of chromate ions, and due to competitiveness of the oxy-anions of chromium. A high concentration of $\mathrm{H}+$ ions facilitates the adsorption whereas a high concentration of $\mathrm{OH}$ - ions suppresses the adsorption reaction, thus accounting for the decrease in the adsorption percentage of $\mathrm{Cr}(\mathrm{VI})$ ion at high $\mathrm{pH}[3]$.

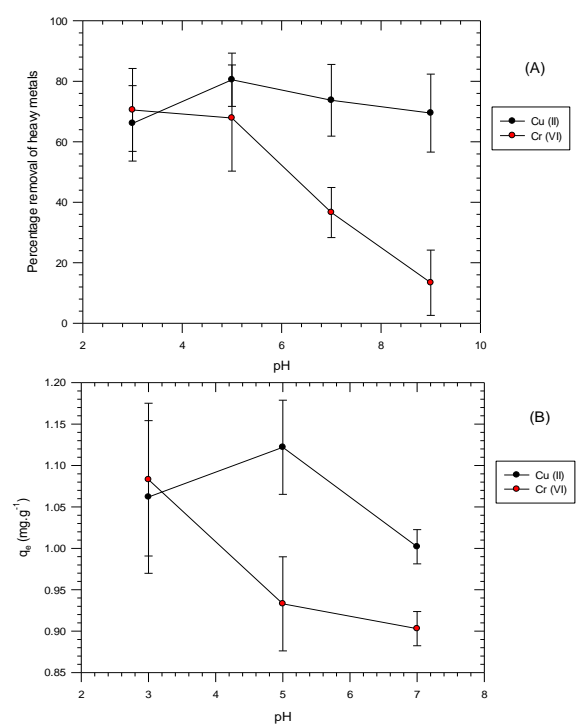

Fig. 3. Effect of $\mathrm{pH}$ on $\mathrm{Cr}(\mathrm{VI})$ and $\mathrm{Cu}(\mathrm{II})$ removal by PKP in (A) synthetic water and (B) raw waste water. $50 \mathrm{mg}$ of PKP was added to $150 \mathrm{ml}$ of 1.0 $\mathrm{mgL}^{-1}$ of the metal ions. The $\mathrm{pH}$ value was adjusted at from 3 to 9 at $200 \mathrm{rpm}$ for $70 \mathrm{~min}$ at $25^{\circ} \mathrm{C}$.
Also, the effect of $\mathrm{pH}$ on the percentage of $\mathrm{Cu}(\mathrm{II})$ removal by PKP was shown in Fig. 3. The results reveal that there is a decrease in removal of metal ions at lower $\mathrm{pH} 3$ is apparently due to the higher concentrations of $\mathrm{H}^{+}$in the solution, which compete with $\mathrm{Cu}$ (II) ions for the adsorption sites of the adsorbents. Generally, the positive charge of the adsorbent surface decreases with the increasing $\mathrm{pH}$ value to $\mathrm{pH} 5$, leading to the decrease in the repulsion between the adsorbent surface and $\mathrm{Cu}(\mathrm{II})$, thus improving the adsorption capacity [14], [15]. At higher $\mathrm{pH}$ values than 5, the percentage removal and adsorption capacity due to metal precipitation (metal hydroxides precipitate) appeared and adsorbent was deteriorated with accumulation of metal ions. Therefore, $\mathrm{pH} 5$ was selected to be the optimum $\mathrm{pH}$ for further studies [13]. The extent of $\mathrm{Cr}(\mathrm{VI})$ and $\mathrm{Cu}(\mathrm{II})$ adsorption onto PKP was greatly dependent on the solution $\mathrm{pH}$.

Adsorption isotherms. Freundlich isotherm assumes that the uptakes of metal ions occur on a heterogeneous surface by multilayer adsorption and that the amount of adsorbate adsorbed increases infinitely with an increase in concentration. This isotherm does not predict any saturation of the sorbent by the sorbate thus infinite surface coverage is predicted mathematically, indicating a multilayer sorption of the surface using the following equation [7], [16], [17].

$$
\log q_{e}=\log K_{F}+\frac{1}{n} \log C_{e}
$$

$C_{e}$ is the equilibrium activities of metal ions and $q_{e}$ is the surface activity for metal ions on the solid surface [16]. Both $K_{F}$ and $\mathrm{n}$ are Freundlich constants. The numerical value of $1 / \mathrm{n}$ $<1$ indicates that adsorption capacity is only slightly suppressed at lower equilibrium concentration. The values of $1 / n$ and $K_{f}$ can be calculated from the slope and intercept of the plot, respectively.

Langmuir isotherm is applied to equilibrium adsorption assuming mono-layer adsorption onto a surface with a finite number of identical sites using the following equation [18].

$$
\frac{c_{e}}{q_{e}}=\frac{1}{q_{m} b}+\frac{c_{e}}{q_{m}}
$$

In which $q_{e}\left(\mathrm{mg} \cdot \mathrm{g}^{-1}\right)$ is the equilibrium adsorption capacity of adsorbent; $C_{e}$ is the equilibrium concentration of the adsorbate; $q_{m}\left(\mathrm{mg} \cdot \mathrm{g}^{-1}\right)$ is the maximum adsorption capacity corresponding to complete monolayer coverage, $b$ is the Langmuir constant related to the adsorption energy and $K_{L}$ is adsorption constant, $K_{L}=q_{m} . b$. A plot of $C_{e} / q_{e}$ versus $C_{e}$ resulted in a straight line of slope $1 / q_{m}$ and an intercept of $1 / b . q_{m}$.

The correlation coefficient $\left(\mathrm{R}^{2}\right)$ and $\mathrm{q}_{\mathrm{m}}$ values that are regarded as a measure of the goodness-of-fit of experimental data on the isotherms model as shown in Table I. The $\mathrm{R}^{2}$ values were elucidated that the Langmuir isotherm model represents a poor mathematical fit, while it is well fitted with the Freundlich isotherm model indicating the presence of heterogeneous sites. These results were in good agreement with previous research in a similar system [14].

Adsorption Kinetics. The linear form of LFO model was 
applied in this study can be expressed by Eq. 3 The PSO kinetic model is given by Eq. 4 [19].

$$
\begin{gathered}
\ln \left(q_{e}-q_{t}\right)=\ln q_{e}-k_{1} t \\
\frac{t}{q_{t}}=\frac{t}{k_{2} q_{e}^{2}}+\frac{t}{q_{e}}
\end{gathered}
$$

In which $q_{t}\left(\mathrm{mg} \cdot \mathrm{g}^{-1}\right)$ is the amount of adsorption time (min); $q_{e}$ is the amount of adsorption equilibrium (mg. $\left.\mathrm{g}^{-1}\right) \cdot K_{1}$ and $K_{2}$ are the adsorption rate coefficients (rate constants) of the equations $\left(\mathrm{min}^{-1}\right) . K_{1}$ can be determined experimentally by plotting of $\ln \left(q_{e}-q_{\mathrm{t}}\right)$ versus $t$. The applicability of PSO model can be examined by linear plot $\left(t / q_{t}\right)$ versus $t$. Slopes and intercepts are respectively $1 / q_{e}$ and $1 / \mathrm{k}_{2} \mathrm{q}_{\mathrm{e}}{ }^{2}$. The experimental data were evaluated by LFO and PSO models, which gave linear plots, Figures not shown, respectively. The rate constants and the calculated adsorption capacity qe of each model were determined and listed in Table II. For LFO study, it was found that the calculated $q_{e}$ values did not agree with the $q_{e \text { exp }}$ values which suggested that the LFO model gives a poor fitting. For PSO model, the $R^{2}$ values were 0.9980 and 1, Table II. The calculated and experimental capacities were fitted well using PSO. This result was in good agreement with previous research in a similar system [9], [20]. Thus, the PSO kinetics is the obeyed model for the biosorption of $\mathrm{Cr}(\mathrm{VI})$ and $\mathrm{Cu}$ (II) onto PKP since it has higher $R^{2}$ values than that obtained from the LFO model.

\begin{tabular}{|c|c|c|c|c|c|}
\hline \multicolumn{6}{|c|}{ Freundlich constants } \\
\hline & $\mathrm{K}_{\mathrm{F}}$ & & & \multirow{2}{*}{\multicolumn{2}{|c|}{$\pm \mathrm{SD}$}} \\
\hline Metal & $\left({\mathrm{L} . \mathrm{g}^{-1}}^{-1}\right.$ & $1 / \mathrm{n}$ & $\mathrm{R}^{2}$ & & \\
\hline $\mathrm{Cr}(\mathrm{VI})$ & 6.47 & 0.872 & 0.9998 & \multicolumn{2}{|c|}{0.018} \\
\hline $\mathrm{Cu}(\mathrm{II})$ & 6.45 & 0.747 & 0.986 & \multicolumn{2}{|c|}{0.136} \\
\hline \multicolumn{6}{|c|}{ Langmuir constants } \\
\hline & $\mathrm{q}_{\mathrm{m} \cdot \exp }$ & & $\mathrm{K}_{\mathrm{L}}$ & \multirow[b]{2}{*}{$\mathrm{R}^{2}$} & \multirow[b]{2}{*}{$\pm \mathrm{SD}$} \\
\hline Metal & $\left(\mathrm{mg} \cdot \mathrm{g}^{-1}\right)$ & $b$ & $\left(\mathrm{~L} . \mathrm{g}^{-1}\right)$ & & \\
\hline $\mathrm{Cr}(\mathrm{VI})$ & 394 & 0.0163 & 6.4 & $\begin{array}{c}0.961 \\
4\end{array}$ & 0.016 \\
\hline $\mathrm{Cu}(\mathrm{II})$ & 332 & 0.0143 & 4.75 & 0.631 & 0.094 \\
\hline
\end{tabular}

TABLE I: LANGMUIR AND FREUNDLICH BIOSORPTION CONSTANTS

* Fifty $\mathrm{mg}$ of PKP was added to $150 \mathrm{ml}$ of various concentrations $(1-1000$ $\left.\mathrm{mgL}^{-1}\right)$ of $\mathrm{Cr}(\mathrm{VI})$ or $\mathrm{Cu}(\mathrm{II})$ and stirred at $200 \mathrm{rpm}$ for $70 \mathrm{~min}$ at $25^{\circ} \mathrm{C}$. $\mathrm{SD}=$ standard deviation.

Environmental study. In order to demonstrate a practical application value of this research, a real waste water sample from El-Souif waste crater, Alexandria, Egypt, was collected and added to the PKP. After 70 min stirring, the maximum removal of metal ion studied at different $\mathrm{pH}$ values was in order $\mathrm{Cu}(\mathrm{II})>\mathrm{Cr}(\mathrm{VI})$, Fig. 3. It was found to be at lower $\mathrm{pH}$ values of the raw waste water sample as compared to higher $\mathrm{pH}$ values. $\mathrm{Cr}(\mathrm{VI})$ has the maximum recovery at $\mathrm{pH} 3$ which was $87.8 \%$, while $\mathrm{Cu}(\mathrm{VI})$ had the maximum recovery at $\mathrm{pH} 5$ which found to be $88.2 \%$. It was also noticed that the $\mathrm{q}_{\mathrm{e}}$ for heavy metals decreased in the raw waste water sample in comparison with the synthetic waste water system which was reported above in Fig. 3A. This may be due to several reasons which could be due to the lower initial concentrations $(144-280 \mathrm{ppb})$ relative to our previously studied value $(1 \mathrm{ppm})$ or the competition between metals are present in El-Souif wastewater crater. Moreover, the environmental study was performed on a raw waste water samples which contain many different metal ions which could be enhanced the adsorption capacity of metal ions onto the adsorbent surface [21]. The results above clearly suggest that the used adsorbents possess has a potential application value.

TABLE II: LFO AND PSO PARAMETERS FOR THE ADSORPTION OF CR(VI)

\begin{tabular}{|c|c|c|c|c|c|}
\hline \multirow[b]{2}{*}{ Metal } & \multicolumn{5}{|c|}{ Pseudo-first-order model } \\
\hline & $\begin{array}{l}\text { qe.exp. } \\
\left(\mathrm{mg} \cdot \mathrm{g}^{-1}\right)\end{array}$ & $\begin{array}{c}\mathrm{K} 1 \\
\left(\mathrm{~min}^{-1}\right)\end{array}$ & $\begin{array}{l}\text { qe.cal. } \\
\left(\mathrm{mg.g}^{-1}\right)\end{array}$ & $\mathrm{R}^{2}$ & $\pm \mathrm{SD}$ \\
\hline $\mathrm{Cr}(\mathrm{VI})$ & 90.39 & 0.075 & 55.2 & 0.9854 & 0.187 \\
\hline $\mathrm{Cu}(\mathrm{II})$ & 76.2 & 0.071 & 48.1 & 0.971 & 0.244 \\
\hline & \multicolumn{5}{|c|}{ Pseudo-second-order model } \\
\hline Metal & $\begin{array}{l}\text { qe.exp. } \\
\left(\mathrm{mg}^{-1} \mathrm{~g}^{-1}\right)\end{array}$ & K2 & $\begin{array}{l}\text { qe.cal . } \\
\left(\mathrm{mg.g}^{-1}\right)\end{array}$ & $\mathrm{R}^{2}$ & $\pm \mathrm{SD}$ \\
\hline $\mathrm{Cr}(\mathrm{VI})$ & 90.39 & 0.003 & 94.6 & 1 & 0.005 \\
\hline $\mathrm{Cu}(\mathrm{II})$ & 76.2 & 0.003 & 81.2 & 0.998 & 0.02 \\
\hline
\end{tabular}
AND CU(II) ONTO PKP AT VARIOUS INITIAL CONCENTRATIONS

*Fifty $\mathrm{mg}$ of PKP was added to $150 \mathrm{ml}$ of $1-1000 \mathrm{mg} \mathrm{L}^{-1}$ of the metal ions. The $\mathrm{pH}$ value was adjusted to 3 for $\mathrm{Cr}(\mathrm{VI})$ and 5 for $\mathrm{Cu}(\mathrm{II})$. The suspensions were stirred at $200 \mathrm{rpm}$ for $70 \mathrm{~min}$ at $25{ }^{\circ} \mathrm{C}$. $\mathrm{C}_{0}=$ initial heavy metal concentration

\section{CONCLUSIONS}

PKP has proven to be a promising material for removal of pollutant from environmental waters due to a fairly high capacity to remove $\mathrm{Cr}(\mathrm{VI})$ and $\mathrm{Cu}(\mathrm{II})$ ions from solution. The extent of $\mathrm{Cr}(\mathrm{VI})$ and $\mathrm{Cu}(\mathrm{II})$ adsorption onto PKP was found to be largely dependent on solution parameters such as metal ion type, initial metal ion concentration, biosorption dosage, solution $\mathrm{pH}$ and solvent used. The adsorption capacities of the used adsorbents toward $\mathrm{Cu}(\mathrm{II})$ was higher than those determined toward $\mathrm{Cr}(\mathrm{VI})$. The adsorption data of $\mathrm{Cr}(\mathrm{VI})$ and $\mathrm{Cu}$ (II) was best fitted with Freundlich isotherm more than Langmuir isotherm indicating the presence of heterogeneous sites on PKP for $\mathrm{Cu}(\mathrm{II})$ and $\mathrm{Cr}(\mathrm{VI})$. Adsorption Kinetics was followed the pseudo-second order rate equation. The adsorption capacity of heavy metals was increased in the presence of the real waste water sample when compared to the synthetic waste water system.

\section{ACKNOWLEDGMENTS}

The authors acknowledge the financial support provided by chemistry department Faculty of Science, University of Sirte, Libya.

\section{REFERENCES}

[1] A. Abou-Shady, C. Peng, H. Bi, J. Xu, and J. Almeria, "Recovery of Pb (II) and removal of $\mathrm{NO}_{3}$ - From aqueous solutions using integrated electrodialysis, electrolysis, and adsorption process," Desalination, vol. 286, pp. 304-315, 2012.

[2] F. Ge, M. Li, H. Ye, and B. Zhao, "Effective removal of heavy metal ions $\mathrm{Cd}^{2+}, \mathrm{Zn}^{2+}, \mathrm{Pb}^{2+}, \mathrm{Cu}^{2+}$ from aqueous solution by polymer-modified magnetic nanoparticles," Journal of Hazardous Materials, vol. 211-212, pp. 366-372, 2012. 
[3] T. Altun and E. Pehlivan, "Removal of Cr (VI) from aqueous solutions by modified walnut shells," Food Chemistry, vol. 132, pp. 693-700, 2012.

[4] E. Ofomaja, "Equilibrium studies of copper ion adsorption onto palm kernel fibre," Journal of Environmental Management, vol. 91, pp. 1491-1499, 2010.

[5] M. Ackacha, "Removal of $\mathrm{Pb}$ (II) from aqueous solution by portulaca oleracea leaves: Kinetic, equilibrium and thermodynamic studies," American Journal of Analytical Chemistry, vol. 4, no. 7, pp. 27-32, 2013.

[6] N. Karapinar and R. Donat, "Adsorption behaviour of $\mathrm{Cu}^{2+}$ and $\mathrm{Cd}^{2+}$ onto natural bentonite," Desalination, vol. 249, pp. 123-129, 2009.

[7] M. Erhayem and M. Sohn, "Effect of humic acid source on humic acid adsorption onto titanium dioxide nanoparticles," Science of the Total Environment, vol. 470, no. 471, pp. 92-98, 2014.

[8] I. Langmuir, "The adsorption of gases on surfaces of glass, mica and platinum,” J. Am. Chem. Soc., vol. 40, pp. 1361-1368, 1918.

[9] W. Amarasinghe and A. Williams, "Tea waste as a low cost adsorbent for $\mathrm{Cu}$ and $\mathrm{Pb}$ removal from waste water," Chemical Engineering Journal, vol. 132, pp. 299-309, 2007.

[10] K. Bhattacharya, K. Naiya, N. Mandal, and K. Das, "Cr(VI) Ions removal from aqueous solutions using natural adsorbents - FTIR studies," Chemical Engineering Journal, vol. 137, pp. 529-541, 2008.

[11] H. F. R. Heiba, "Removal of some toxic heavy metal ions from their mixtures using adsorption technique," M.Sc. Thesis, Faculty of Alexandria university, Egypt, 2012.

[12] M. Nieto, D. Alami, G. Hodaifa, C. Faur, S. Rodriguez, A. Gimenez, and J. Ochando, "Adsorption of iron on crude olive stones," Ind. Crops Prod, vol. 32, pp. 467-471, 2010.

[13] A. Sari, D. Mendil, M. Tuzen, and M. Soylak, "Biosorption of Cd(II) and $C r$ (III) from aqueous solution by moss (Hylocomium splendens) biomass: Equilibrium, kinetic and thermodynamic studies," Chemical Engineering Journal, vol. 144, pp. 1-9, 2008.

[14] C. Erdogan and S. Ulku, "Cr (VI) sorption by using clinoptilolite and bacteria loaded clinoptilolite rich mineral. microporous and mesoporous," Materials, vol. 152, pp. 253-261, 2012.
[15] L. Singh, R. A. Pavankumar, R. Lakshmanan, and G. K. Rajarao, "Effective removal of $\mathrm{Cu}^{2+}$ ions from aqueous medium using alginate as biosorbent," Ecological Engineering, vol. 38, pp. 119-124, 2012.

[16] N. Karapinar and R. Donat, "Adsorption Behaviour of $\mathrm{Cu}^{2+}$ and $\mathrm{Cd}^{2+}$ onto Natural Bentonite,” Desalination, vol. 249, pp. 123-129, 2009.

[17] M. Erhayem, F. Al-Tohami, R. Mohamed, and K. Ahmida, "Isotherm, kinetic and thermodynamic studies for the sorption of mercury (II) onto activated carbon from rosmarinus officinal is leaves," American Journal of Analytical Chemistry, vol.6, pp. 1-10, 2015.

[18] I. Langmuir, "The adsorption of gases on surfaces of glass, mica and platinum," J. Am. Chem. Soc., vol. 40, pp. 1361-1368, 1918.

[19] W. Amarasinghe and A. Williams, "Tea waste as a low cost adsorbent for $\mathrm{Cu}$ and $\mathrm{Pb}$ removal from waste water," Chemical Engineering Journal, vol. 132, pp. 299-309, 2007.

[20] K. Bhattacharya, K. Naiya, N. Mandal, and K. Das, " $\mathrm{Cr}(\mathrm{VI})$ ions removal from aqueous solutions using natural adsorbents — FTIR studies," Chemical Engineering Journal, vol. 137, pp. 529-541, 2008.

[21] H. F. R. Heiba, "Removal of some toxic heavy metal ions from their mixtures using adsorption technique," M.Sc. Thesis, Faculty of Alexandria university, Egypt, 2012.

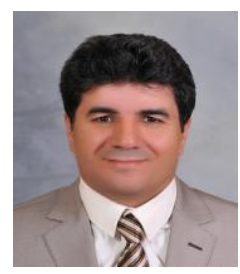

Ragwan Mohamed was born in 1966. He graduated in chemistry in 1989 from Benghazi University and obtained his M.Sc degree in analytical chemistry in 2006 from Cairo University. He completed his Ph.D in environmental chemistry from Alexandria, Egypt, in 2013 .

He is currently working as lecture at University of Sirte. Also, he is currently the dean of faculty of science at University of Sirte Branch Abokreen. He has published over 4 articles in international journals and has presented several research papers at various international conferences. His research interests include adsorption, kinetics, thermodynamics, agricultural waste materials, heavy metals and others.

Dr. Ragwan is an Asia-Pacific Chemical, Biological \& Environmenta Engineering Society (APCBEES) member since 2014 under ID 201308. 